\title{
Impact of Demonetization on Financial Inclusion and Digital Payments
}

\author{
Shivali Veen, Sonia Kamboj
}

\begin{abstract}
It was the night of 8th November 2016, when the Government of India demonetized high value currency notes of Rs.500 and Rs.1000. It implied that these two denominations are denied the status of legal tender. The intention behind demonetization was to curb black money and fight corruption and counterfeit currency. Counterfeiting of Indian currency has been a means for promoting terror activities in the world and Indian government aimed to tackle this through demonetization. These notes were replaced with new set of currency notes of Rs.500 and Rs.2000. Demonetization is not a new concept in India and has happened thrice in the past on 12th January 1946, 16th January 1978, and 8th November 2016. The aim of the present study is two fold- Firstly to understand the concept of demonetization and the reasons behind it. Secondly, to analyse its impact on financial inclusion and digital payments. As defined by World Bank-"Financial inclusion means that individuals and businesses have access to useful and affordable financial products and services that meet their needs - transactions, payments, savings, credit and insurance delivered in a responsible and sustainableway".

Digital payment, on the other hand, means using digital technology to send and/or receive money.

For the present study, data related to Indian economy has been collected from Global Findex database, as provided by World Bank, for three different time periods; 2011, 2014 and 2017. Results have shown that demonetization has had a positive impact on both financial inclusion and digital payments.
\end{abstract}

The results would be useful for future studies on demonetization and for policy implications of the government. Index Terms - Black money, Demonetization,Digital Payments, Financial Inclusion..

\section{INTRODUCTION}

It was the night of 8th November 2016, when the Government of India demonetized high value currency notes of Rs.500 and Rs.1000. It implied that these two denominations are denied the status of legal tender. The intention behind demonetization was to curb black money and fight corruption and counterfeit currency. Counterfeiting of Indian currency has been a means for promoting terror activities in the world and Indian government aimed to tackle this through demonetization. The intentions of Indian government were highly appreciated at that time but it was the execution of such a drastic step which caused pain to the population of 132 crore (approx.). During 2016, these Rs.500 and Rs.1000 notes were around $86 \%$ of the currency in circulation, which is a substantial part of money in circulation

Shivali Veen, Assistant professor, Department of Commerce, Kalindi College, University of Delhi

Sonia Kamboj Assistant professor, Department of Commerce, Kalindi College, University of Delhi, 110008 and hence it created a monetary turmoil.

\section{A. History of Demonetization.}

\section{A.History of Demonetisati}

History of demonetization in India reveals a story about the previous attempts of demonetization by different governments at different time periods. For the first time, it happened in 1946 when high value currency notes of Rs.500, Rs.1000 and Rs.10,000 were demonetized and replaced by new currency notes. Also in 1978, the then government again planned and executed demonetization of Rs.1000, Rs.5000 and Rs. 10,000. After 38 years, the Prime Minister Mr. Narender Modi led government decided to shock the economy by demonetizing Rs 500 and Rs 1000 notes and replacing them by Rs.500 and Rs.2000notes.

It was a shock to the entire nation and led to lot of hardships to the general public. People were forced to stand in long queues, for exchanging these old currency notes to new ones, which led to chaos, anger, resentment and even deaths. Daily wage earners were hit the hardest, as they not only lost the revenue in these days but many of them working in the unorganised sector lost their jobs also. Industry suffered due to loss of man hours. Loss of GDP and industry closures were also reported in newspapers. The preparation level of government and RBI to print new currency was also not quite high.

The government, however praised the move stating it will curtail all the black money in the economy, and would put a stop on counterfeit currency. Finance minister also stated that it will improve digitisation and hence would lead to a cashless economy. The government was of the strong view that it will lead to higher tax compliance and more tax revenues.

In the present study, an attempt has been made to review the level of financial inclusion and digital payments in India. In order to do this, firstly this paper talks about concept of demonetization and history of demonetization. There is also a need to know the purpose of such a drastic step form the point of view of government.

\section{LITERATURE REVIEW}

Microfinance Institutions help in providing financial services to the low income and under - served or un-served population. CARE ratings (November,2016) reveals that due to not as much of cash transactions in the short run, some of the major sectors and sections will face short term disruptions 
until the new notes are widely circulated in the economy.

Mali (December 2016) in a study examines that disbursement of cash and collection of instalments by micro finance institutions will slow down due to unavailability of cash.

MFIN micrometer (2016) reports that the total loan disbursement number fell down by $26 \%$ in the 3 rd quarter of F.Y. 2016-17 in contrast to the 3rd quarter of F.Y. 2015-16. Portfolio at risk also greater than before to $7.52 \%$ in the $3 \mathrm{rd}$ quarter of F.Y. 2016-17 from half a percentage in 2nd quarter of FY 2016-17.

Waknis (March 2017) in his study observes that there will be depression in the Indian economy for at least few quarters and formal firms mostly based on physical cash based transactions will be exaggerated.

The Microfinance industry has passed through a big transformation from merely a finance raising source for the semi-urban and rural people to the direct means of helping them in running theirown business noted PWC (2016).It further points that despite growth in MFIs, the operational efficiency of small and mid- size MFIs are more prone to risk due to internal and external challenges.

Ratna (2016) signifies that since microfinance sector depends on physical cash it will be one of the most vulnerable businesses due to demonetization. The revitalization of this sector will totally depend on the amount of cash supply in near future.

The Economic Times(2016) states that the industry is facing repayment issues in the poll bound states like Uttar Pradesh, Uttarakhand and Karnataka leading to the deterioration in the quality of loan assets.

India rating and research (2016) examines that due to cash crisis the repayment capacity of the borrowers will be slowed down as this businesses are face risk of over-leveraged borrowers.

Sasyak (2016) in a study exposed that demonetization will spoil incomes of many labor class and short term contract employees and it is expected that the growth of the economy will fall for twoquarters.

Chowdhry and Associates (2016) postulates that due to fall in cash transactions another forms of payments like $\mathrm{E}$ banking, E wallets and apps, plastic money and other digital mode of transactions will boost.

Singhal, S. (2017) studied the impact of the demography on the awareness level in customers about e- bankingservices, in order to find the variation between customers of urban and ruralareas, find the reasons for the same and suggest way forward. The paper accepted E-banking to be a buzzword afterdemonetization. Identified that rural population would take little longer to adapt to internet based banking and also found that usage rate of smart phones have gone up.

Ghosh, c., \&ghosh, a. (2008) decided to develop a macrotheoretic model to examine the likely impact of demonetization in India and found that Demonetization is unlikely to produce much of an impact on the age group of black income and counterfeit notes. But, it will surely harmfully affect the most helpless sections of thepeople.
Mehta, S., Patel, K., \& Mehta, K. (2016) concluded that demonetization helped the government to track people who are having large sums blackmoney. However, they also emphasized that it is not enough just

to do demonetization. It needs to be matched with a better, more sleek and integrated tax system.

Jha, B. (2017) analyze the impact of demonetization on the collection efficiency and disbursement of loan amount of NBFC-MFIs. The paper found out that NBFC-MFIs had a hard time both in terms of collection efficiency anddisbursements as demonetization was rigid on this sector. In addition, after remonetisation, there have been some sign of recovery in this sector but still its progress will depend on the stride of currency replenishment in the economy, the medium to long term impact of demonetization.

\section{OBJECTIVE OF THESTUDY}

The aim of the present study is as follows-

- To understand the concept ofdemonetization.

- To review the history of demonetization inIndia.

- To understand the reasons or motivation behind such step taken bygovernment.

- To understand the concept of financialinclusion.

- To analyze its impact on financial inclusion and digitalpayments.

\section{METHODOLOGY OF THESTUDY}

- The present study is based on data collected through various secondary sources of information, such as research papers, articlesetc.

- The data for financial inclusion for our country has been collected from "The Global financial inclusion (Global Findex) database" of the World Bank.

\section{CONCEPT OFDEMONETIZATION}

Demonetization is the act of stripping a currency unit of its status as legal tender. 1 Demonetization is not a new concept in India and has happened thrice in the past on 12th January, 1946, 16th January, 1978, and 8th November, 2016.

While people were allowed to exchange their old notes for valid currency, deposit the money, or withdraw a certain amount from the ATM, the move saw unprecedented lines outside banks and ATMs with bank employees working overtime to make up for the cash crunch in the common man's life.

The move to make currency illegal overnight has, however, happened earlier, both times with a view to interrupt black money deals and tender black money hoarded as illegal. By putting a cap on the money that one is able to deposit without coming under the scanner of the Income Tax department, the government aimed at investigating possible tax evasions aswell.

The three sets of demonetization were as follows-

1. 12thJanuary, 1946.

2. 16th January, 1978

3. 8th November, 2016. 


\section{A. First demonetization in India:-}

The government of India announced on 11th of January, 1946, that high denomination notes of Rs. 500, Rs. 1000 and Rs. 10,000 would not remain legal tender from 12th January, 1946. The idea behind such move was to curb black marketing. It was again a shock at that time to the general public and as a result many people were found dead because of such a shock, there were long lines at the bank and the general public was financially hithard.

At that time, old notes were allowed to be

sold at 60 and 70 per cent of the price.

Rumors started growing regarding demonetization of Rs. 100 notes alongside the high denomination currency and it lead to a panic situation where people lost trust and started changing their Rs. 100 notes also.

\section{B. Second demonetization in India:-}

It happened during January, 1978, where government of India decided to take a harsh step of demonetizing the Indian currency of high value denominations of Rs. 1000, Rs. 5000 and Rs. 10,000. The intention behind this demonetization was same as that of the previous one, of curbing black money.

\section{Third demonetization in India:-}

On 8th November, 2016, the government of India, led by our prime minister Shri Narender Modi, made an announcement that from the midnight of 8th November, 2016, high denomination currency of Rs.500 and Rs. 1000 would not remain legal tender. It was a panic situation for the general public as it came as a shock to them and there were again long lines of people outside the banks wanting to deposit the money in their bank account. The intentions were again in line with the previous two demonetizations of curbing black money and fighting the malice of counterfeit currency. The idea was also to fight terrorism.

1 Investopedia (Updated Apr 12, 2019)

\section{REASONS/MOTIVES BEHIND DEMONETIZATION}

1. To curb black money: One of the major reason behind demonetization was to curb black money. Not only business houses but also high net worth individuals had a huge amount of unaccounted money, but due to this step of Indian Government, this black money was deposited in banks. Black money, in simple terms mean, unaccounted money or the money on which tax has not been paid or has beenevaded.

2. To fight against counterfeit currency: As per the report of Indian Statistical Institute, around 70 crores fake currency notes are entered in economy every year, but the actual figures may be higher than this. The step of demonetization which Indian government took, sucked all this fake money from the system as new currency notes were introduced with high securitymeasures.

3. To fight against terrorism: Funding for terrorist operations has been stopped as fake currency is the major source of financing for terrorist activities. Also demonetization kept a check on hawala transactions through which these terrorist groups receive funding.

4. To decrease the level of corruption in the country:
Corruption happened due to the parallel economy being present in the country, which was due to black money. With targeting black money, demonetization also aimed at fighting corruption levels in the country.

5. To improve financial inclusion levels in the country: One of the major aim was to increase the deposit base in the banks, promote financial services across country and promote financialliteracy.

6. To promote digital payments: This was another reason for demonetization as there were restrictions on cash transactions

on a particular day whereas any payment through digital mode was much easier and supported bygovernment.

7. To curb tax evasion and enhance tax compliance: As majority of the transactions were allowed through digital mode without much restrictions, which on the one side promoted digital payments and on the other hand, in case of digital payments, there was a proper record of every transaction which was helpful to curb tax evasion and enhanced tax compliance.

8. To eliminate the gap between beneficiary of government subsidies and the government. (bringing governance to the governed) : If the targeted beneficiary would have a bank account in his/her own name, it would be easier and transparent for the benefit of government schemes to pass on to suchpersons.

\section{EFFECT OFDEMONETIZATION}

- The expectation of Reserve Bank of India (RBI) at the time of demonetization was different from reality. During 2016, the high denomination currency of Rs 500 and Rs 1000 was around $86 \%$ money in circulation which valued around Rs 15.44 lakh crore. RBI expected that out of this, money valued Rs 10 lakh crore would be returned and rest would account for black money and hence would be driven out of the system. However, the reality was quite different. Money of the value of Rs 15.31 lakh crore (disclosed by RBI, august 2018) was returned to the banking system and only Rs 11000 crore was not returned. This amount constituted only around $0.7 \%$ of the demonetizedcurrency.

- Cost of printing new currency notes and handling the entire process of demonetization was around Rs 21000 crore. This led to reduction of profits ofRBI.

- There was increase in the deposits in specific accounts namely, Saving bank deposit accounts, PMJDY accountsetc.

- Labour force in the unorganised sector was hit hard, as they work on daily wages and they lost huge amount of their revenue. There was loss of man hours due to they being in the long queues of banks. They also suffered due to closure of manyunits.

- Normal banking suffered in the days of demonetization as bank employees were busy converting old currency into newcurrency.

\section{DEMONETIZATION'S IMPACT ON FINANCIAL INCLUSION AND DIGITAL PAYMENTS - ANANALYSIS}

For analyzing the impact of Demonetization on financial inclusion, data has been collected from "The Global financial 
inclusion (Global Findex) database" of the world bank. Its been described as the world's most comprehensive data set for data related to financial inclusion, digital payments, savings, borrowings etc.(Demirgüç-Kuntet al. 2018: xv).

\section{A. Global Financial Inclusion (Global Findex)Database}

The Global Findex database is the world's most comprehensive data set on how adults save, borrow, make payments, and manage risk. Launched with funding from the Bill \& Melinda Gates Foundation, the database has been published every three years since 2011 . It provides more than 200 indicators on topics such as account ownership, payments, saving, credit, and financial resilience. Global Findex data is reported for all indicators by country, region, and income group. Available indicators are reported for 2017, 2014, and 2011.2

For this analysis, firstly it is imperative to introduce the two important and related concepts of financial inclusion and digital payments.

\section{Global Findex Overview.}

\section{A. Financial Inclusion}

The world bank group has a goal of reaching "Universal Financial Access(UFA) by 2020, as it considers "financial inclusion as a key enabler to reduce extreme poverty and boost shared prosperity."

As defined by World Bank- "Financial inclusion means that individuals and businesses have access to useful and affordable financial products and services that meet their needs - transactions, payments, savings, credit and insurance - delivered in a responsible and sustainable way".

- The aim behind improving financial inclusion is to increase the general public's financial access and also improve the day to day living standards. As people get access to a bank account, then they also start accessing other financial services such as debit cards, credit cards, net banking, investing in various options like mutual funds, PPF accounts, and accessing loansetc.

- India is one of those emerging economies where there are many poor households who are not financially literate and also do not have a basic bank account. These households live or survive on daily income basis and thus are reluctant to keep their money in banks or invest it in some schemes. Not only this, they are not even aware of the functions of banks properly and thus are unware of the benefits banks can provide to them. Thus, financial literacy and access to financial services become a major deterrent in financialinclusion.

- Other reason which might act as a deterrent to accessing financial services like an opening a bank account are the requirements laid down by such banks like minimum income, credit score criteria, age criteria, minimum balance to be maintained, etc. For accessing a loan such criteria become even more stringent like work experience, or current salary, collateral requirements, proper documentationetc.

- Not only access but also affordability should be improved. Affordability of financial services also act as a barrier to the under-privileged sections ofsociety.

- Financial inclusion should aim at not only access of financial services but also their regular use by the targetedpopulation.

- When it comes to credit, poor and uneducated sector normally dependent upon the informal ways of borrowing which are not sustainable. In this process, they often get misguided and end up paying enormous amount as interest. This requires awareness to be spread to all sections of society about formal means of getting credit, which is in turn a part of financialinclusion.

\section{B. Major Financial Inclusion Schemes inIndia}

Different schemes have been launched at different points of time and by different governments in India. Some of the major schemes are:
a. Pradhan Mantri Jan Dhan Yojana(PMJDY)
b. Atal Pension Yojana(APY)
c. Pradhan Mantri Vaya VandanaYojana
d. Stand Up India Scheme

e. Pradhan Mantri MudraYojana

f. Pradhan Mantri Suraksha Bima Yojana (PMSBY)

g. Sukanya SamriddhiYojana

h. Jeevan Suraksha BandhanYojana

i. Credit Enhancement Guarantee Scheme (CEGS) for Scheduled Castes(SCs)

j. Venture Capital Fund for Scheduled Castes under the Social SectorInitiatives

$$
\text { C. Varishtha Pension Bima Yojana(VPBY) }
$$

\section{H.Objectives of Financial Inclusion}

a. Financial inclusion's aim is to make financial services such as deposits, fund transfers, loans etc. easily and affordablyaccessible.

b. For this aim to be achieved, proper rules and regulations are required along with financialinstitutions.

c. It aims to develop a habit of saving and also of investing in the general public, which makes them maintain their financial health infuture.

d. In this process, people would require consultations and assistance, in order to choose the correct financial service for them. Competition in such area, would help them choose the betteroption.

e. Awareness about government schemes and their benefits should reach the targeted poor and economically under-privileged sections for whom such schemes were made. Financial inclusion aims to help in such awareness process. Thus, financial literacy would also be enhanced in thecountry.

f. It aims to ensure such benefits is actually passed on to the beneficiary and hence there is a need of them having their own proper bankaccount.

g. It aims to provide mobile banking, e- banking or other internet related financial services to masses of the country, even if they live in extreme remoteareas. 
h. Financial solutions depend upon individual needs, household preferences, living standards, level of income, financial condition, number of people in a family, number of bread earners in the family, etc. Hence, they have to be tailor made as per specifications.

D. Digital payment

It's a payment mechanism which uses digital modes. The sending and receiving both are conducted electronically through digital modes. This simply means, its cashless transaction. Its better than cash transactions as it is more convenient, easy, safe and less risky.

It can happen through a lot of modes such as -

i. UPIapps

ii. AEPS (Aadhar enabled payment service)

Table 1: Percentage of people having an account.

\begin{abstract}
iii. Cards - Debit or creditcards
\end{abstract}
iv. E-wallets (such as Paytm),etc.

\section{DATA ANALYSIS}

A. Financial Inclusion : The Findex defines having an account (\% age $15+)$ as "the percentage of respondents who report having an account (by themselves or together with someone else) at a bank or another type of financial institution or report personally using a mobile money service in the past 12 months and having age above 15." This set of data includes both male and female (refer to Table 1).

\begin{tabular}{|l|l|l|l|l|l|}
\hline $\begin{array}{l}\text { Country } \\
\text { Name }\end{array}$ & $\begin{array}{l}\text { Country } \\
\text { Code }\end{array}$ & Series Name & $\begin{array}{l}\text { 2011 } \\
\text { [YR2011] }\end{array}$ & $\begin{array}{l}\text { 2014 } \\
\text { [YR2014] }\end{array}$ & $\begin{array}{l}\text { 2017 } \\
\text { [YR2017] }\end{array}$ \\
\hline India & IND & $\begin{array}{l}\text { Account } \\
\text { age 15+) }\end{array}$ & 35.2 & 53.1 & 79.9 \\
\hline India & $\begin{array}{l}\text { Account, } \\
\text { female (\% age 15+) }\end{array}$ & 26.5 & 43.1 & 76.6 \\
\hline India & IND & $\begin{array}{l}\text { Account, male } \\
(\% \text { age 15+) }\end{array}$ & 43.7 & 62.8 & 83 \\
\hline $\begin{array}{l}\text { Data from database: Global Financial Inclusion } \\
\text { Last updated : 10/15/2018 }\end{array}$ & IND
\end{tabular}

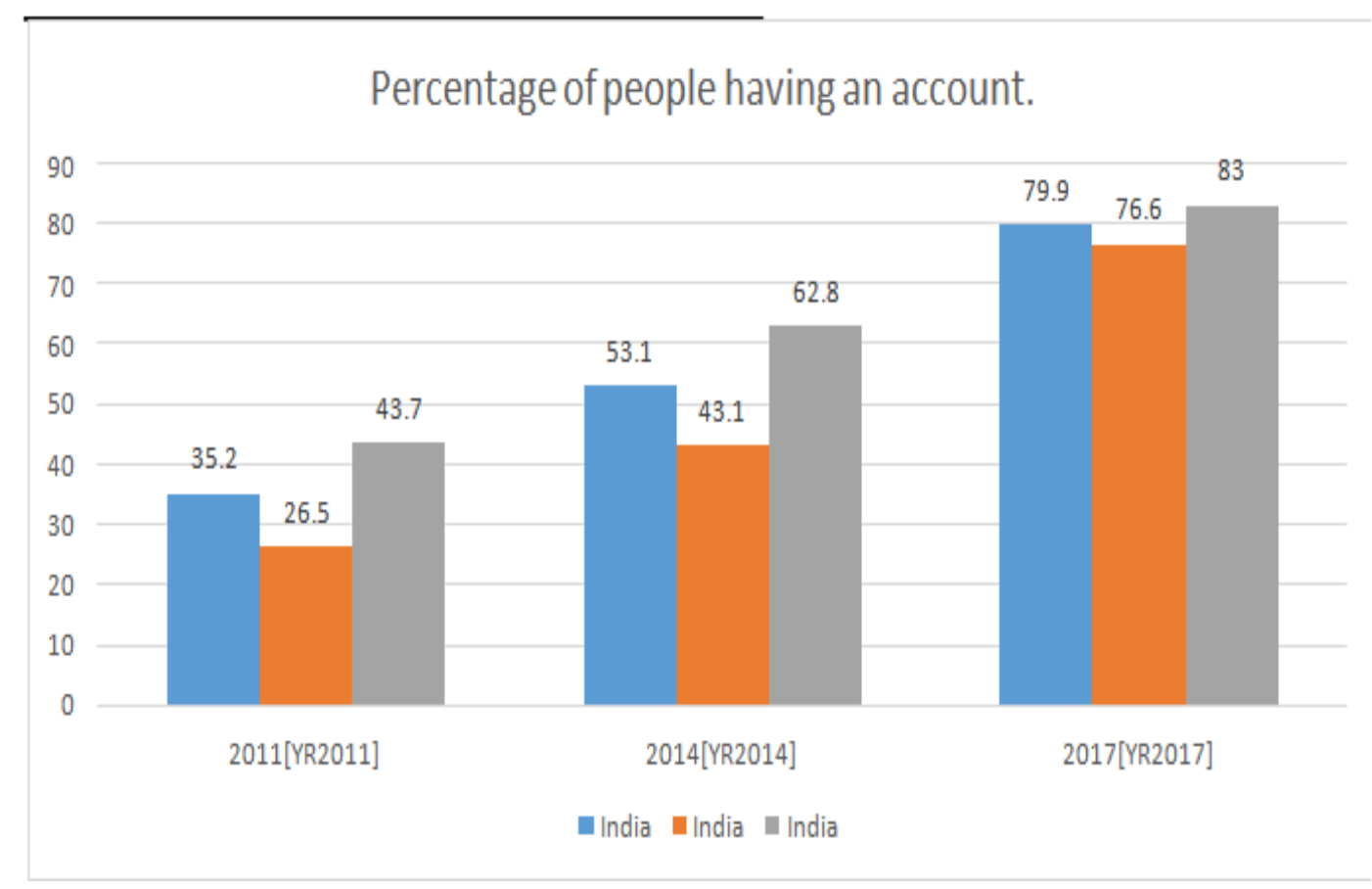

Figure 1:Percentage of people having an account

The above figure reveals that for 2014, when the "2016" demonetization did not happen the percentage of people (age $15+$ ) having an account at a bank or other financial institution was $53.1 \%$ as compared to $35.2 \%$ in 2011 . This percentage increased to $79.9 \%$ in 2017 , the post demonetization period. This shows successful increase in terms of financial inclusion.

This could be more clearly understood,

if we segregate the data in terms of gender.

As both Table 1 and figure 2 indicates, the percentage of females (age 15+) in 2017 was $76.6 \%$, which shows a tremendous increase from the pre-demonetization period (2011 and 2014). The above figures reveals that in 2011 this percentage for females was $26.5 \%$ and for 2014 it was 43.1 . 
For males (age 15+), the data set again shows an increase in financial inclusion. As compared to 2011 where this percentage for men was $43.7 \%$ and for 2014 was $62.8 \%$, this percentage rose to $83 \%$ in 2017 , postdemonetization.

If the two data sets are compared for both males and females, in 2017 the percentage of females reporting to have I an account were $76.6 \%$ and for males it was $83 \%$, clearly indicating the gap on the basis of gender. It stipulates that the government need to not only promote financial inclusion but come up with schemes for that attract more women to participate and be part of the formal financial sector of theeconomy.

The data also reveals that rise in women's accounts was faster than men's accounts (Figure 2 and 3).

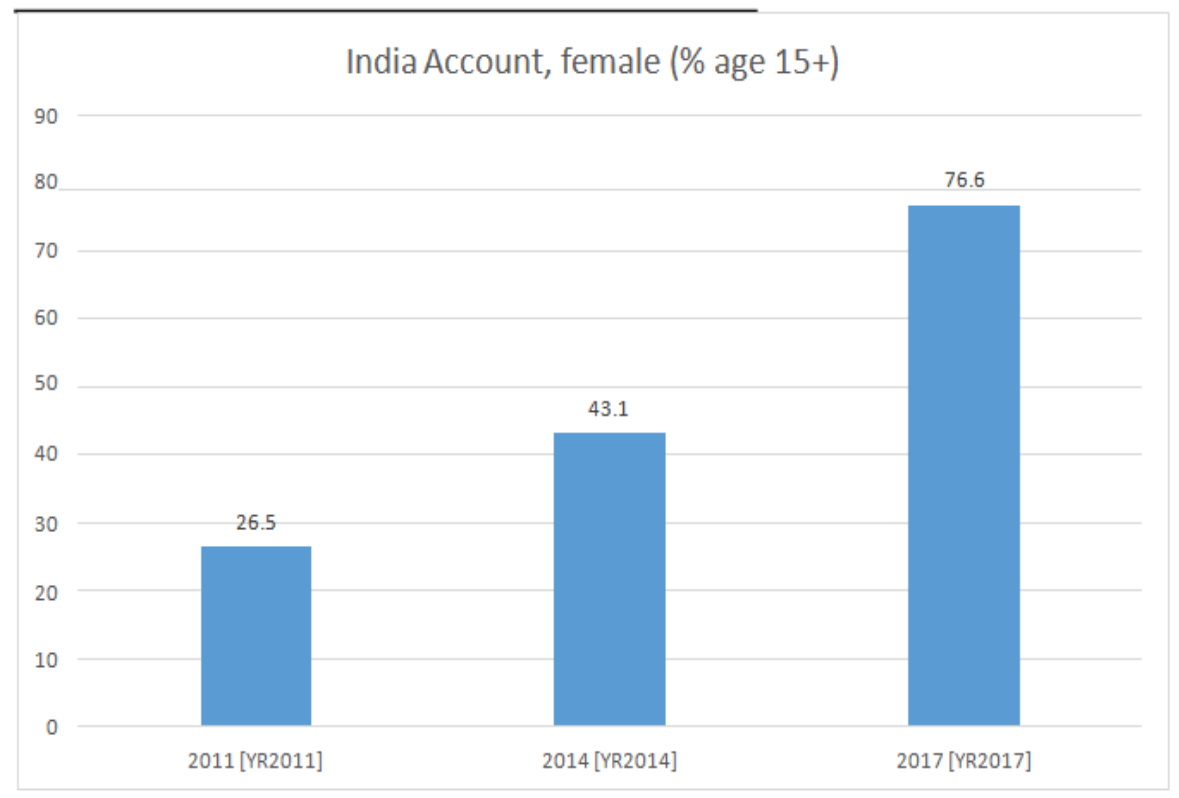

Figure 2:Percentage of females (age 15+) has an account.

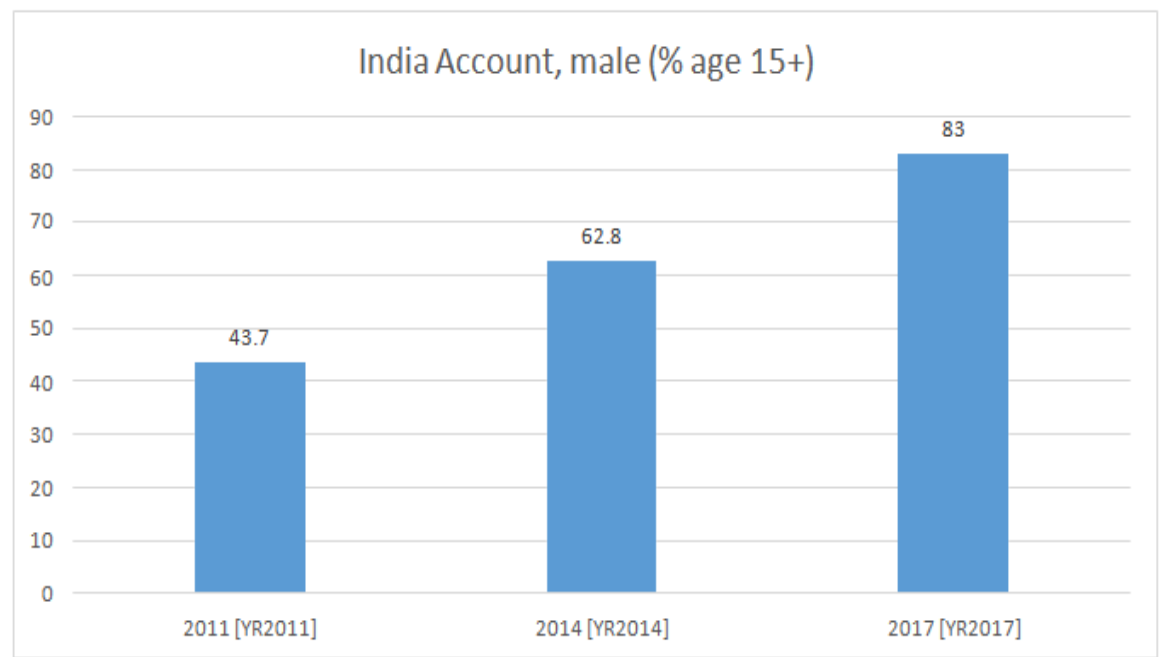

Figure 3: PercentageofMales(age15+)hasanaccount.

a. Digital Payments : The Findex defines having Made digital payments in the past year $(\%$ age $15+)$ as "The percentage of respondents who report using mobile money, a debit or credit card, or a mobile phone to make a payment from an account, or report using the internet to pay bills or to buy something online, in the past 12 months. It also includes respondents who report paying bills or sending remittances directly from a financial institution account or through a mobile money account in the past 12 months." (refer to table 2) 
Table 2: Percentage of people reported using digital payments (age 15+)

\begin{tabular}{|l|l|l|l|l|l|}
\hline $\begin{array}{l}\text { Country } \\
\text { Name }\end{array}$ & $\begin{array}{l}\text { Country } \\
\text { Code }\end{array}$ & SeriesName & $\mathbf{2 0 1 1}$ & $\mathbf{2 0 1 4}$ & $\mathbf{2 0 1 7}$ \\
\hline & $\begin{array}{l}\text { Made digital payments in } \\
\text { the past year (\% } \\
\text { age 15+) }\end{array}$ & & & \\
India & IND &. & 15.7 & 20 \\
\hline $\begin{array}{l}\text { Data from database: Global Financial Inclusion } \\
\text { Last updated : } 10 / 15 / 2018\end{array}$
\end{tabular}

The above table reveals that the percentage of respondent reporting using digital payments (Age 15+) for 2017 has been $20 \%$ as increased from $15.7 \%$ in 2014 . This shows an increase in the digital payments done in this time period. This can be shown from the following figure (figure 4)

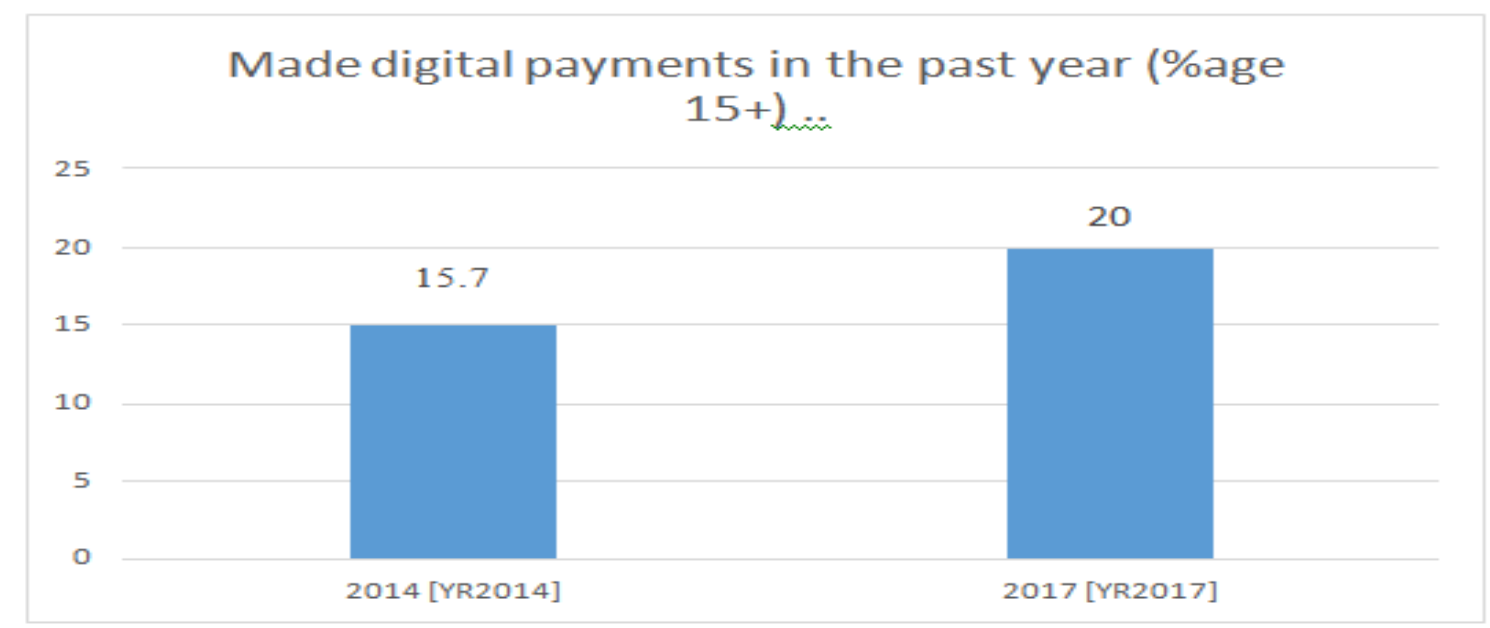

Figure 4: Percentage of people reported using digital payments (age 15+)

Table 3: Percentage of female reported using digital payments (age 15+)

\begin{tabular}{|l|l|l|l|l|l|}
\hline $\begin{array}{l}\text { Country } \\
\text { Name }\end{array}$ & $\begin{array}{l}\text { Country } \\
\text { Code }\end{array}$ & Series Name & $\begin{array}{l}\text { 2011 } \\
\text { [YR2011] }\end{array}$ & $\begin{array}{l}\text { 2014 } \\
\text { [YR2014] }\end{array}$ & $\begin{array}{l}\text { 2017 } \\
\text { [YR2017] }\end{array}$ \\
\hline India & $\begin{array}{l}\text { Made digital } \\
\text { payment in the past year, } \\
\text { female } \\
(\% \text { age } 15+)\end{array}$ &.. & 7.9 & 13.5 \\
\hline $\begin{array}{l}\text { Data from database: Global Financial Inclusion } \\
\text { Last updated : } 10 / 15 / 2018\end{array}$ & & & \\
\hline
\end{tabular}

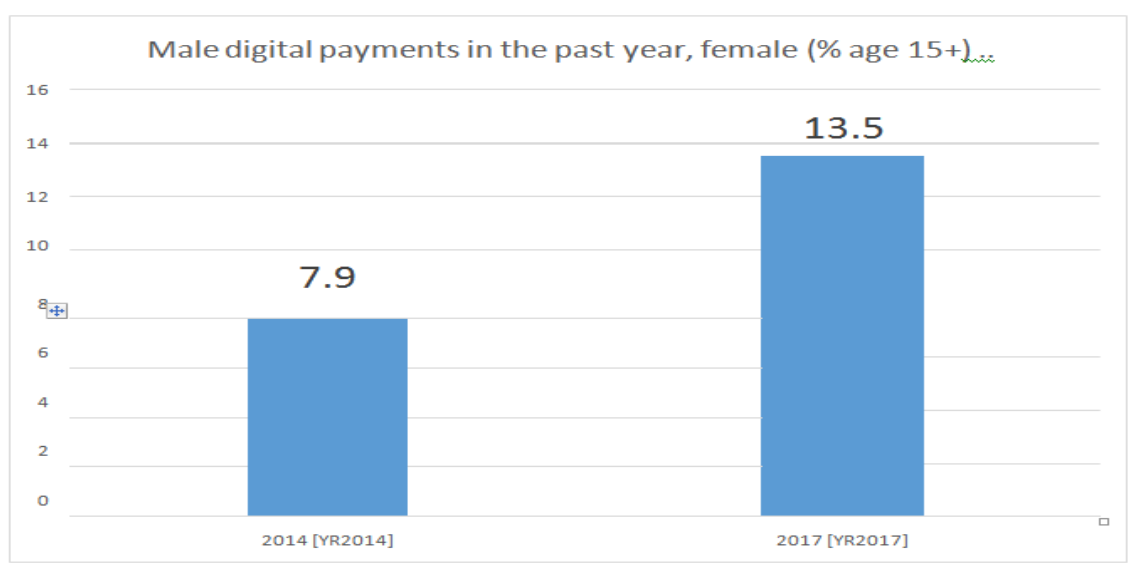

Figure 2: Percentage of female reported using digital payments (age 15+) 
As far as female percentage is concerned, the trend showed an increase to $13.5 \%$ in 2017 (post-demonetization period) from $7.9 \%$ in 2014 (pre-demonetization period).(figure 5)

Table 3: Percentage of male reported using digital payments (age 15+)

\begin{tabular}{|l|l|l|l|l|l|}
\hline $\begin{array}{l}\text { Country } \\
\text { Name }\end{array}$ & $\begin{array}{l}\text { Country } \\
\text { Code }\end{array}$ & $\begin{array}{l}\text { Series } \\
\text { Name }\end{array}$ & $\begin{array}{l}\text { 2011 } \\
\text { [YR2011] }\end{array}$ & $\begin{array}{l}\mathbf{2 0 1 4} \\
\text { [YR2014] }\end{array}$ & $\begin{array}{l}\text { 2017 } \\
\text { [YR2017] }\end{array}$ \\
\hline & $\begin{array}{l}\text { Made digital } \\
\text { payments in } \\
\text { the past } \\
\text { year, male } \\
(\% \text { age15+) }\end{array}$ &.. & & \\
India & IND & & 23.3 & 26.2 \\
\hline $\begin{array}{l}\text { Data from database: Global Financial Inclusion } \\
\text { Last updated : 10/15/2018 }\end{array}$ & & \\
\hline
\end{tabular}

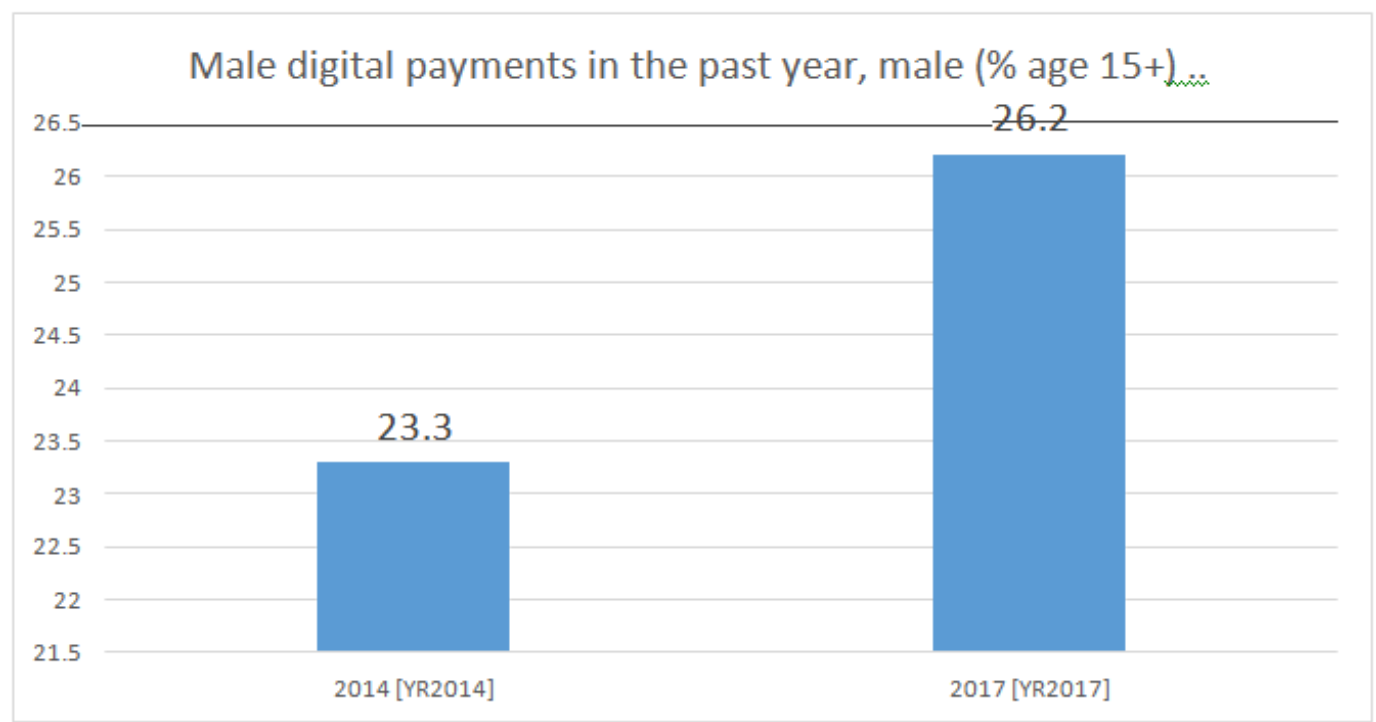

Figure 6: Percentage of Male reported using digital payments (age 15+)

Figure 6 reveals an increase from $23.3 \%$ in 2014 to $26.2 \%$ in 2017 for male respondents. Thus, its clearly showed that this increase in digital payments transactions was more for female respondents as compared to male respondents.

The date for the year 2011 was not available for digital payments.

\section{CONCLUSION}

Cashless economy and financial inclusion were major objectives of the exercise of Demonetization. The idea was to make the economy shift from being cash based economy, where most transactions settle in cash, to being a cashless economy. However, this cannot happen overnight or with one or two drastic steps. Achieving cashless economy is a complex process, which require infrastructural support, financial literacy, cyber security, rules and regulations, availability of high speed internet to the masses, more schemes like PMJDY, private and government participation, etc. Demonetization was considered to be a behavioural break or a regime shift where people would change their age old habits of depending upon cash settlement oftransactions.

The data above reveals increase in percentage of financial inclusion as well as digital payments, both for male and female respondents. Even though an increase is shown from pre demonetization period to post demonetization period, it cannot be solely attributed to demonetization, as enormous other factors could have affected such an increase.

\section{REFERENCES}

[1] Demonetization," Manohar Chowdhry\& associates, accessed on March 20 ,

http://www.mca.co.in/knowledge-centre/demonetization-mca.

[2] "Micrometer", MFIN, accessed on April 4, 2017, http://mfinindia.org/wp-content/uploads/2016/10/Micrometer-Issue-20 _Q3-FY-16-Feb-2017_public_16th-Feb-2107.pdf.

[3] "Shifting trends in the microfinance ecosystem", PWC, accessed on April6, 2017,http://www.pwc.in.

[4] Daya,H.\&Mader,P.(2018).DidDemonetizationAccelerateFinancialIncl usion?

[5] Economic \& political weekly, 53(45), 17.

[6] "Demonetization: Three times India faced the big move", November 18,2016 , the indianexpress.

[7] Demirguc-Kunt, Asli; Klapper, Leora; Singer, Dorothe; Ansar, Saniya; Hess, Jake Richard. 2018. The Global Findex Database 2017: Measuring Financial Inclusion and the Fintech Revolution (English) Washington, D.C.: World BankGroup.

[8] GHOSH, C., \& GHOSH, A. (2008). Economics of the public sector PHI Learning Pvt.Ltd...

[9] https://www.worldbank.org/en/topic/financialinclusion/overview

[10] Jha, B. (2017). Impact of Demonetization on Microfinance Institutions in India--A Study. AAYAM: AKGIM Journal of Management, $7(1), 15$.

[11] Mali, V (2016), "Demonetization: A step towards modified India", "International Journal of Commerce and Management Research," 2(12),35-36.

[12] Mehta, S., Patel, K., \& Mehta, K. (2016). Demonetization: shifting gears from physical cash to digital cash. Voice of Research, 5(3), 47-50. 
[13] Pattnaik, S. (2017). Exploring the effects of demonetization in India. accessed on April, 7.

[14] Ray, Atmadip (2017, January 27)."MFI sector yet to get over demonetizationimpact".The Economic Times,Retrieved from http:// economictimes.indiatimes.com/industry/banking/finance/mfi-sector-ye t-to-get-over-demonetization-impact/ articleshow/56810668.cms

[15] Singhal, S. (2017). Demonetization and E-banking in India. International Journal of New Technology and Research,3(1).

[16] Vishwanathan, Ratna, "Currency demonetization is a welcome move for various reasons," India Info line news service, accessed on April 8, 2017, http://www.indiainfoline.com.

[17] Waknis, Parag (2017), "Demonetization through segmented markets: Sometheoretical perspectives", "Economic \& Political Weekly,"52(9). 